\title{
リポート ゴム技術フォーラム創立10周年を迎えて
}

事務局長 鈴 木 守

\section{1.はじめに}

ゴム技術フォーラムが発足して10年が経過いた しました。設立 10 周年にあたり，平成 7 年11月 29 日(水)東京南青山の「はあといん乃木坂」において 「記念特別公開フォーラムと神原 周先生, 古川 淳二先生への謝恩と長寿を祝う会」が開催され, 100名を超す出席者でにぎわいました。その模様を 記して，ゴム技術フォーラムが目的のひとつとす る技術情報交流の一助といたしたいと思います。

ゴム技術フォーラムは, ゴム工業の新しい展開 をさぐク, 併せて先端産業との関連を研究するこ とを目的として，古川淳二先生の提唱によって昭 和61年発足以来, 平成 7 年11月現在まで111回にも 及ぶセミナ一，見学会を開催してまいりました。

フォーラムの会員は，一般会員（各企業より2 名, ゴム加工メーカー, 原料メーカー約 30 社), 特 別会員 (学識経験者約20名), 顧問で構成されてお ク, 会の運営は月例会として, ほぼ月 1 回, 講演 会を開催しています。例会は夕刻から始まり, 講演終了後には軽い食事をとりながら講師を囲ん で討論，会員相互の交流を深めるとともに情報交 換の場ともなっております。

また，ゴム技術フォーラムでは，昭和63年度か ら月例会のほか，特定テーマによる調査委員会を 発足させて次のようなテーマで調査検討を行い, 各年度末に開催の公開フォーラムにて調査結果を 発表し, 更に報告書としてとりまとめ出版してお ります。

(1) 昭和62年 転換期の高分子工業

(2) 平成 2 年 90 年代に向けての日本企業のグ ローバリゼーション

(3) 平成 3 年 ゴム工業における技術予測 一自動車タイヤを中心としてー

(4) 平成 4 年 特殊エラストマーの未来展開を さぐる一特殊ゴムの高性能化一 (5) 平成 5 年 特殊エラストマーの未来展開を
(6) 平成 6 年

さぐる一特殊ゴムの高機能化一 ゴム加工の未来展開をさぐる -21世紀に向けて一

\section{10周年記念特別公開フォーラム}

ゴム技術フォーラム設立10周年記念特別公開フ オーラムは, 影山邦夫運営委員の司会によって, 山崎 升先生, 古川淳二先生, 神原 周先生によ る記念講演が行われました。 その概要を記します。

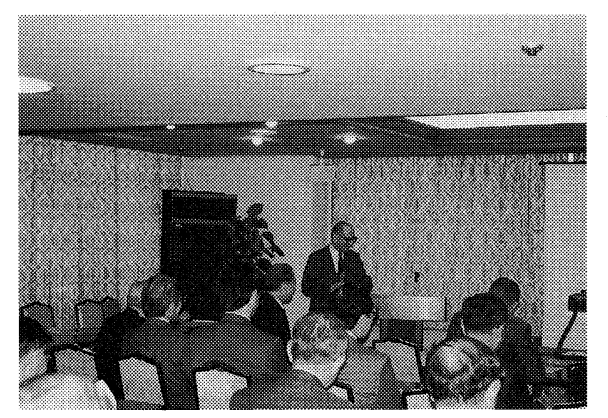

\section{1 免震ゴムをめぐる話題}

東京工業大学 名誉教授 山崎 升氏

山崎先生は, 先の阪神・淡路大震災とロスアン ゼルスの地震を比べながら, 口ス地震と阪神・淡 路大震災が全く同じ 1 年の差で起きていること, 建物の崩壊は阪神・淡路は火災もあってロスの 10 倍, 死者は口スの 50 人に対して阪神・淡路は 5,000 人余りに達している, と日米の免震の相異につい て下記のとおり，わかりやすく解説されました。

（1）アメリカと日本との免震建築には, 非常に大 きな差がある。アメリカにおける免震建築は28棟 あり, 大部分が裁判所, 病院, 図書館など公共の 建物に多い。

（2）日本には，そうした建物にはおそらく使用さ れていないだろう。アメリカではレトロフィット といわれる歴史的建物, 例之ば裁判所, 市庁舎な 
ぞ大変な費用と労力をかけて保存に力を注いでい る. 日本の考え方と大きな違いではないか.

（3）阪神・淡路大震災で叫ばれた危機管理につい てアメリカでは約 $3000 \mathrm{~m}^{2}$ の敷地に約 600 億円をか けて危機管理センターが造られている，民家を離 れた丘にあり，外部からのエネルギー補給がなく とも一週間は生活できるようになっている.

（4）免震用積層ゴムに対する問題は耐久性, 耐老 化性であるが，充分に信頼できる．経費的には建 築当初の值段は高くつくかも知れないが, 設備や 家具などの損害, 免震を使用することにより建物 上部の強度を多少小さめにできるなど, 決して高 価ではない。

（5） 原子力発電所の原子炉の寿命は 40 年といわれ ており，その下に免震ゴムを入れる研究がされて いる. 昭和 56 年に完成していた原子力発電所は平 成 8 年で 20 年になる. 原子力研究所に申し入れ, 取り出してデー夕をとるという話を聞いている. 大きな実証になると思う。

\section{2 ゴム協会と私との60年 \\ 京都大学 名誉教授 古川淳二氏}

古川先生は，京大卒業時にゴム協会に入会した 経緯から，戦時中の合成ゴム，戦後のゴム工業と ゴム協会, 更にはゴム協会の将来などについて何 時までもお若い，亡ネルギッシュな語り口で，時 折りユーモアを交えながら講演されました。

（1）1936年に京大を卒業したが，卒業間際に当時 の帝国発明協会が募集した恩賜発明奨励賞に喜多 源逸先生の推めで合成ゴムの研究を行い, 賞金と して当時の 1 万円をいただいた。

（2）合成ゴムは，ドイツが第一次世界大戦のとき アセトンを原料としてメチルゴムを造って，Uボ 一トの電池用ケースのエボナイトに使用した。戦 争で合成ゴムが必要となり各国で研究を始めた。

（3）日本では，昭和14年合成ゴム小委員会が設立 され田中芳雄先生が幹事長となってニトリルゴ ム, ブタジエンゴムを造り, 大阪の朝日新聞社で 合成ゴム研究発表会を開催した。

（4）戦後は，日本合成ゴム侏）日本ゼオン(侏)よ゙ が設立され，ブタジエンゴムを米，英，独にも輸 出されるようになった，合成ゴムが造られるよう になってゴム物性の研究に与えた影響は大きい. 当時, 久保亮五先生が「ゴム弾性」の本を書かれ たが，近々これの復刻版が出版されることを聞い ている.

\section{3 新しい合成ゴムを夢みて 東京工業大学 名誉教授 神原 周氏} 神原先生は, いま日本で大変困っている問題と して変圧器, コンデンサーに使用されている PCB （ポリクロロビフェニル）があると指摘された。 変圧器, コンデンサーの寿命は $10 〜 25$ 年で, PCB を取り替えなければならない. PCBには毒性があ りこれを処理するためには膨大な費用を必要とす るため問題となっている。そこで，チオコール系 合成ゴムを造る夢をみた，と89歳とは思之ないほ ど警鑠として夢を語って下さいました。

(1) 多硫化物系合成ゴムであるから，アルコール の結合部分があり毒性が強い。これをどう避ける かが難しい.

（2）この毒性の問題は，いろいろ方法はあろうが， 四硫化ナトリウムで毒性をなくして充てん剤とし て木材, 石材, ガラス, 金属微粉末やアスファル トなどを使って新しいゴム製品を造ることがで きる。

（3）毒性を除きながら，合成ゴムを造る仕事を夢 みている.お集まりの皆さんの中で「できそうだ。 やってみよう.」とお考えの方は，どなたでもやっ てほしい。皆さんのお知恵を帱借したい。

\section{3. 神原先生, 古川先生への謝恩と長寿を祝う会}

前述の記念特別公開フォーラム終了後, 午後 4 時45分から会場を「はあといん乃木坂」の地下 1 階宴会場に移して開催されました. 参加者の中に は, 神原先生, 古川先生ゆかりの方々ばかり, こ れほど多くの関係者の方々が一堂に会する機会は 滅多になく，「謝恩と長寿を祝う会」に入る前に両 先生を囲んで記念写真を撮りました（図 2 ).

「謝恩と長寿を祝う会」は，まず，ゴム技術〉 オーラム 横瀬恭平代表から,「神原, 古川両先生 は，ともに教育者であり，ゴムに造詣が深く，ア イデアマンで，ゴム産業の将来を真剣に考えて下 さっていることが共通点, 常に我われを御指導下 さり，感謝申しあげている，先の講演でもお叱り を受けたようで，目が覚める思い」と挨拶されま した，次いで，来賓として東京大学名誉教授 岩 倉義男氏, 日本学術会議第 5 部長 内田盛也氏, 日本ゴム工業会専務理事 今井晋作氏が挨拶に立 ち, 東京工業大学名誉教授 山崎 升氏の音頭で 乾杯，祝宴に入りました。

宴なかばで, (財)生産開発科学研究所理事長 山 
下晋三氏，(侏ブリヂストン顧問 吉村信哉氏，日 本合成ゴム侏副社長 谷山、巌氏の挨拶に続き, 神原, 古川両先生に花束と記念品の贈呈が行われ ました。

最後に神原，古川両先生の御挨拶を頂戴し，日 本ゴム協会 西 敏夫会長の閉会の挨拶で午後 6
時30分謝恩パーティを締めくくりましたが, 出席 者の方々は，何時までも名残惜しむかのように歓 談されていました。

我が国ゴム技術界の重鎮として神原 周先生と 古川淳二先生の益々の御健勝を祈念いたしまして 擱筆いたします。

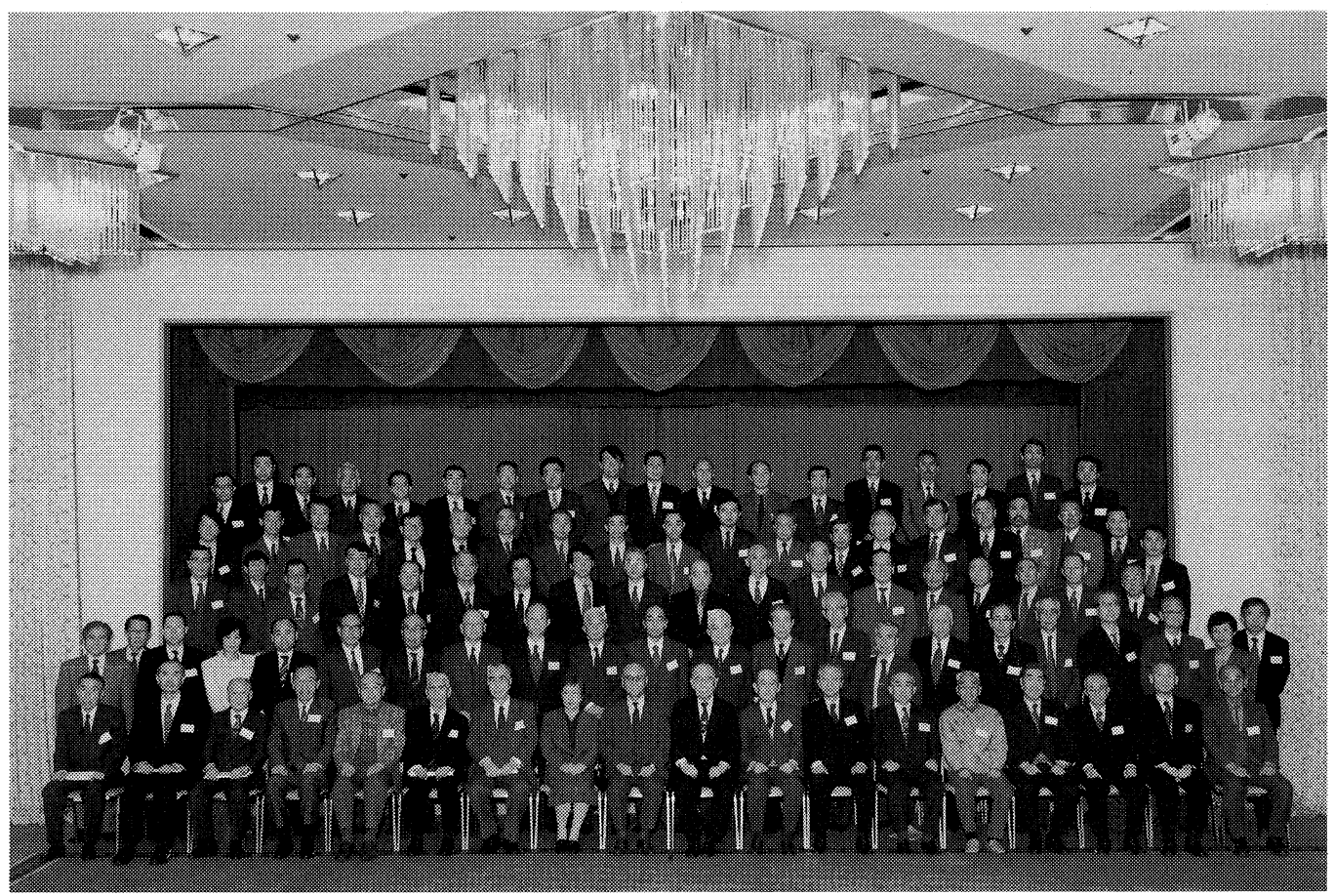

